\title{
Key Techniques Involved in Recovering Gingival Recessions: Literature Review
}

\section{Laura Renilde Lucas da Silva Lemos ${ }^{1}$, Amanda de Macedo Silva ${ }^{1}$, Gabriel Gomes da Silva ${ }^{1}$, Daniel Felipe Fernandes Paiva ${ }^{2}$, Juliana Campos Pinheiro ${ }^{3}$, and Rafaella Bastos Leite ${ }^{4 *}$}

${ }^{1}$ Graduando em Odontologia pela Universidade Federal do Rio Grande do Norte, Natal, Rio Grande do Norte, Brasil ${ }^{2}$ Cirurgião-dentista, graduado pela Universidade Federal do Rio Grande do Norte, Natal, Rio Grande do Norte, Brasil ${ }^{3}$ Cirurgiã-dentista, Doutoranda em Biologia Experimental pela Universidade Federal do Rio Grande do Norte, Natal, Rio Grande do Norte, Brasil ${ }^{4}$ Cirurgiã-dentista, Doutora em Patologia Oral pela Universidade Federal do Rio Grande do Norte, Natal, Rio Grande do Norte, Brasil

*Corresponding author: Rafaella Bastos Leite, Cirurgiã-dentista, Doutora em Patologia Oral pela Universidade Federal do Rio Grande do Norte, Natal, Rio Grande do Norte, Brasil, E-mail: rrafaella_bastos@hotmail.com

Received: 29 Oct, 2019 | Accepted: 08 Nov, 2019 | Published: 14 Nov, 2019

Citation: da Silva Lemos LRL, de Macedo Silva A, da Silva GG, Paiva DFF, Pinheiro JC, et al. (2019) Key Techniques Involved in Recovering Gingival Recessions: Literature Review. J Surg Open Access 6(1): dx.doi.org/10.16966/2470-0991.199

Copyright: (C) 2019 da Silva Lemos LRL, et al. This is an open-access article distributed under the terms of the Creative Commons Attribution License, which permits unrestricted use, distribution, and reproduction in any medium, provided the original author and source are credited.

\section{Abstract}

Introduction: Gingival recession can be defined as the apical dislocation of the gingival margin in relation to the amelio-cementary junction, or in relation to its original site, which provides a progressive exposure of the root surface. Its etiology is multifactorial, being more related to mechanical trauma, periodontal diseases and predisposing factors.

Objective: To analyze the main techniques involved in root coverage of gingival recessions as well as to evaluate tissue response, according to different prognoses.

Methodology: A bibliographic survey was conducted from 2006 to 2019 in the databases Lilacs, PubMed and Scielo. The search strategy used was "recession" and "gingival" and "gingival" and "recession" and "treatment". Articles that did not elucidately portray root coverage methods or evaded the study objective were excluded.

Results: The most frequently used techniques were "coronary repositioning flap" and "subepithelial connective tissue graft" because they had more satisfactory results.

Conclusion: The literature points to the subepithelial connective tissue graft as the "gold standard", which, being removed from the patient's own organism, expresses better results in root coverage and also shows positive results in the Acellular Dermal Matrix (MDA), as it is a Allogeneic graft taken from tissue bank donors, minimizing patient discomfort.

Keywords: Gingival recession; Root coverage; Periodontal treatment

\section{Introduction}

Gingival recession or retraction may be defined as the apical dislocation of the gingival margin relative to the amelo-cemental junction or relative to its original insertion site. The loss of gingival conjunctival insertion is not necessarily accompanied by the loss of bone insertion, and promotes progressive exposure of the root surface. The recession may be associated with one or more surfaces, being localized or generalized $[1,2]$.

Many people who have generalized gingival retractions, as they have no symptoms, have no notion of their condition. However, when diagnosed, for reasons such as fear of tooth loss, hypersensitivity and aesthetic reasons, considerable concern can be observed [1].

Gingival retractions have a multifactorial etiology, being more related to mechanical trauma, periodontal diseases and predisposing factors. Excessive force applied during brushing and the use of hard bristled brushes promotes abrasion of the gingival tissues and is the predominant factor for recession in adolescents. The accumulation of dental biofilm (usually resulting from poor oral hygiene) along with the process of inflammation and destruction of periodontal collagen fibers, leading to periodontal disease, is the main cause of gum recession in adults. Finally, since the adjacent tissues may be reduced in size, the bad dental position of the arches will rigorously influence the appearance of retractions, becoming predisposing factors for the appearance of this specific condition [1-3].

It was observed through studies that gingival recession occurs with significant prevalence both in patients with good oral hygiene, as well as those with poor oral health care. Regarding the main age groups related to the onset of recessions, it was found that over $90 \%$ of the elderly population (over 50 years old) had indices of gingival retraction, while $60 \%$ of the young population (up to 20 years old) was affected. It was also evidenced that males have a higher prevalence than females $[1,2]$.

It is known that analyzing the development and possible etiological factors of the diseases is fundamental to help an accurate diagnosis 
and to offer an effective treatment to the patient. Following this line of reasoning, when it comes to gingival recession, classification is essential to have a good prognosis for the case, as well as being a factor that directly interferes with the choice of an effective technique for root coverage. Thus, throughout history, three main types of classifications for gingival recession have come into force, aiming to find the most effective way to categorize it and thus enhance its treatment [4].

The first classification method was proposed in 1968 by Sullivan and Atkins, so that gingival recessions were primarily categorized taking into account only the depth and width of the lesion. Thus, when this method was in effect, gingival recessions were divided into four groups: deep and wide; shallow and wide; deep and narrow; shallow and narrow. In addition, because it is a poorly detailed classification that is lacking in prognosis, this method was later replaced [2,3].

In 1985, Miller's classification became effective, and because of its high criteria for characterizing each of the four subdivisions, in addition to ensuring a more satisfactory prognosis, it remained active until 2018. In Miller's classification method, gingival recessions may be grouped into four classes: in class I, the gingival margin does not reach the mucogingival line and there is no bone or soft tissue loss (interdental tissue); in class II, although the recession reaches or exceeds the mucogingival line, there is no impairment of interdental tissue; in class III, the gingival margin reaches or exceeds the mucogingival line, so that interproximal soft and hard tissue is lost; in class IV, in addition to the gingival recession extending beyond the mucogingival line, there is also the loss of interdental bone apical to the cementumenamel junction. It should be noted that this classification allows for predictability of each clinical case, so that in class I and II recessions a full coverage after the intervention is expected, while in class III the coverage is only partial, and in class IV the result is not. Is predictable due to the severity of the injury [1-3].

Thus, the new classification of periodontal and peri-implant diseases of 2018 further details the gingival retractions, taking into account the loss of interproximal insertion, the gingival phenotype and the characteristics of the exposed root surface to differentiate the classes of these lesions. Unlike previous methods that had four subtypes, the 2018 has only three subtypes; however, although it has a small number, it can offer a more appropriate diagnosis, contributing to an effective treatment. Following this line of reasoning, in type 1 recessions there is no loss of interproximal insertion and cementum-enamel junction is not clinically visible in the mesial or distal; in type 2, the loss of interproximal insertion with distance from the cementum-enamel junction to the bottom of the bag is less than or equal to the loss of vestibular insertion; in type 3 , higher grade, the loss of interproximal insertion is greater than the loss of vestibular insertion, requiring urgent intervention by a specialized professional $[5,6]$. The present study aims to analyze the main techniques involved in root coverage of gingival recessions as well as to evaluate tissue response according to different prognoses.

\section{Methodology}

A bibliographic survey was conducted from 2006 to 2019 in the databases Lilacs, PubMed/Medline and Scielo. For this, we use the following search strategy based on Decs (Health Descriptors) and Boolean operators: "Gingival" and "Recession" and "Treatment". Thus, 148 studies were found, of which 12 were selected for this review.

\section{Results and Discussion}

Firstly, it is essential to emphasize that before starting any surgical procedure of root covering the root surface should not contain bacterial plaque. Thus, prophylaxis should be performed, as well as scraping and root straightening in cases of marked prominence or when there are superficial lesions of root caries, including contributing to the success of the graft and enhancement of tissue regeneration [1].

Root-covering procedures play a major role in periodontal therapy. In addition to correcting gingival recessions with aesthetic implication, they can eliminate root sensitivity, reduce the risk of carious lesions on exposed root surfaces, and restore self-esteem to an individual who until then had his smile compromised. Thus, it becomes evident the importance of analyzing the treatments of periodontal recessions in order to find the most effective treatment and ensure the best possible prognosis for the patient [7].

In addition, root covering techniques have as their primary purpose the reconstruction of anatomical structures and can be evaluated by means of a clinical and biological conception. From a clinical perspective, treatment success can be achieved when the following objectives are achieved: root coverage to the cementumenamel junction, probing depth less than $2 \mathrm{~mm}$, no bleeding on probing, adequate keratinized gingival band ( $\geq 3 \mathrm{~mm}$ ), physiological morphology of the gum, minimal difference in color of adjacent local gum. In the histological understanding, the purpose is to obtain adhesion through periodontal regeneration, with the formation of new cementum, periodontal ligament and alveolar bone.

However, the direct relationship between successful clinical outcomes and periodontal regeneration has not yet been proven, so this goal should be assimilated as ideal. Still, it is expected that, accompanied by complete or partial clinical coverage, healing through a functional epithelium or connective tissue adhesion [3].

The treatment of gingival recessions can be performed through numerous surgical techniques, so it is very common to use simple flaps or to combine them with grafts. One of the most widely used techniques today is the coronary repositioning flap, so this technique is based on the coronal displacement of a flap in order to cover the exposed root surfaces, being possible due to the elastic characteristic of the alveolar mucosa. The main advantages of this method are its simplicity of execution and a non-painful postoperative for the patient. It is also predictable and provides satisfactory aesthetic results for both recessions and localized recessions. Moreover, as it does not require removal of a tissue graft from a donor area, it reduces the risk of contamination and future complications. The main disadvantage of coronary repositioning flap is that this procedure depends on an adequate amount of keratinized gum located apically to recession, a factor that limits this surgical technique $[1,3,7,8]$.

Another commonly used method is subepithelial connective tissue grafting combined with different bilaminary techniques. Being removed from the patient's own organism, the connective tissue graft expressed better results in root coverage, and is considered the "gold standard". It is noteworthy that the success of this surgical technique can be attributed to the double blood supply of the graft, which is interposed between the root surface and the flap. However, the need for two surgical areas (one to obtain the graft and the second to apply the graft) is a significant disadvantage because it subjects the patient to a longer surgical time and a more delicate postoperative period. Among the most common failures that can lead to connective tissue graft failure is flap perforation, graft of inadequate size or thickness, insufficient coronary positioning of flap, absence of bone in the interproximal region, lack of gingival tissue. For covering, poor positioning of connective tissue graft, poor root preparation, among other factors that may interfere with surgical success [9]. 
Given the disadvantages that the use of subepithelial connective tissue graft brings, the use of acellular dermal matrix, as a graft taken from tissue banks, eliminates additional surgery and reduces patient discomfort. The acellular dermal matrix is a graft obtained from human skin and through laboratory processing does not induce an immunogenic response. Thus, it is a graft that promotes healing through cell repopulation and revascularization, thus being a safe and convenient option in root cover treatments. Another alternative for the use of connective tissue grafting is the application of proteins derived from the enamel matrix, a material composed mainly of amelogenin. Its mechanism is similar to the development of the dental follicle in odontogenesis, promoting the production of cement-like mineralized tissue on the root surface, serving as a matrix for cell repopulation and providing reconstruction of periodontal tissues [9-12].

\section{Conclusion}

Based on the analysis of the articles presented, it can be concluded that one of the main decision criteria regarding the choice of root covering technique is the area of aesthetic demand, so that in areas very exposed during the smile or speech is recommended. The use of connective tissue graft surgical techniques that do not use relaxing incisions, as well as improving graft nutrition, prevent scarring and contributes to maintaining the aesthetic smile desired by the patient. Moreover, the connective tissue graft promotes clinical gain of insertion, keratinized tissue and root coverage, being a highly viable alternative indicated for the treatment of Miller class I and II gingival recessions. Another factor taken into consideration regarding the choice of root covering method is the presence or absence of keratinized mucosa and the thickness of the flap or gingival phenotype. Thus, although the coronary repositioning flap technique offers a good aesthetic recovery, it depends on an adequate amount of keratinized gum and therefore often becomes a limited method. Moreover, it was possible to infer that the acellular dermal matrix, being an allogeneic graft taken from tissue bank donors, convinced to be a satisfactory and adequate method, in view of minimizing discomfort, such as the need for two surgical areas. Caused to the patient. Thus, the literature pointed to the subepithelial connective tissue graft technique as "gold standard" because it is a technique with autogenous material and presents better results in the root covering.

\section{References}

1. Zeltner M, Jung RE, Hämmerle CH, Hüsler J, Thoma DS (2017) Randomized controlled clinical study comparing a volume-stable collagen matrix to autogenous connective tissue grafts for soft tissue augmentation at implant sites: linear volumetric soft tissue changes up to 3 months. J Clin Periodontol 44: 446-453.

2. Urban IA, Lozada JL, Nagy K, Sanz M (2015) Treatment of severe mucogingival defects with a combination of strip gingival grafts and a xenogeneic collagen matrix: a prospective case series study. Int J Periodontics Restorative Dent 35: 345-353.

3. Zuhr O, Rebele SF, Schneider D, Jung RE, Hürzeler MB (2014) Tunnel technique with connective tissue graft versus coronally advanced flap with enamel matrix derivative for root coverage: a RCT using 3D digital measuring methods. Part I. Clinical and patient-centred outcomes. J Clin Periodontol 41: 582-592.

4. Dias LZS, Piol SAC, Almeida CSL (2006) Atual classificação de doenças periodontais. Rev Odontol 8: 59-65.

5. Park JB (2006) Increasing the width of keratinized mucosa around endosseous implant using acellular dermal matrix allograft. Implant Dent 15: 275-281.

6. Steffens JP, Marcantonio RAC (2018) Classificação das Doenças e Condições Periodontais e Peri-implantares 2018: guia Prático e Pontos-Chave. Rev Odontol UNESP 47: 189-197.

7. Cunha FA, Hickson AES, Azevedo MYG, Cruz BCV, Cunha MAGM, et al. (2014) Decisão quanto à escolha da técnica de recobrimento radicular. PerioNews 8: 138-144.

8. Felipe ME, Andrade PF, Grisi MF, Souza SL, Taba M, et al. (2007) Comparison of two surgical procedures for use of the acellular dermal matrix graft in the treatment of gingival recessions: a randomized controlled clinical study. J Periodontol 78: 1209-1217.

9. Aroni MAT, Oliveira GJPL, Changoluisa G, Camacho FMT (2016) Coverage of Miller class I and II gingival recessions treated with subepithelial connective tissue graft, acellular dermal matrix, and enamel matrix proteins. Pilot study. Rev odontol UNESP 45: 78-84.

10. Roriz VM, Torres MG, Pinho MN, Andrade APRCB (2011) O uso da matriz dérmica acelular em periodontia: relato de dois casos clínicos. Revista Odontológica do Brasil Central 20: 348-353.

11. Ohana RAEH, Quaresma MC, Menezes SAF, Menezes TOA (2010) Proteína da matriz do esmalte como recurso coadjuvante na terapia periodontal regenerativa. Revista Periodontia 20: 7-13.

12. Venturim RTZ, Joly JC, Venturim LR (2011) Técnicas cirurgicas de enxerto de tecido conjuntivo para o tratamento de recessão gengival. Revista Gaúcha Odontol 59: 147-152. 